\title{
Efektifitas Dakwah melalui Bimbingan kepada Masyarakat (Tinjauan Psikologi Diagnostik) Di Kabupaten Sinjai
}

\author{
Oleh : Meisil B. Wulur ${ }^{1}$ \\ Program Dakwah-Jurusan BPI \\ Sekolah Tinggi Agama Islam Muhammadiyah Sinjai
}

\begin{abstract}
Abstrak
Efektifitas dakwah di Kabupaten Sinjai belum merata, namun upaya-upaya yang dilakukan pemerintahan maupun lembaga yang berbasis Islam sudah cukup baik. Dakwah terhadap masyarakat umumnya para pendakwah hanya sebatas memenuhi panggilan dari penyelenggara kegiatan keagamaan tanpa adanya upaya atau insiatif melakukan dakwah atau bimbingan secara itens dalam berdakwah, dan hanya terfokus pada pembentukan majelis talim yang berlangsung sebulan sekali. Jika ini yang terjadi secara terus menerus maka dakwah yang berada di Kab. Sinjai akan bersifat statis. Berdasarkan tinjauan melalui psikologi diagnostik bahwasannya aktifitas dakwah belum efektif jika ditinjau secara spesifik tapi pada umum sudah cukup baik walaupun belum merata, sehingga upaya melakukan dakwah bimbingan terhadap masyarakat diperlukan adanya analisis masyarakat yang menjadi sasaran dakwah dengan menggunakan "MetodeBimbingan Psikologi Diagnostik", agar setiap permasalahan yang terjadi merupakan kebutuhan dakwah masyarakat, sehingga dapat terdeteksi secara dini. Untuk Kabupaten Sinjai diperlukan adanya diklat pendakwah khusus untuk perempuan karena masih kurangnya pendakwah perempuan.
\end{abstract}

\section{Keyword: Dakwah, Bimbingan, Psikologi Diagnostik}

\footnotetext{
${ }^{1}$ Dosen STAI Muhammadiyah Sinjai
} 


\section{Pendahuluan}

Perkembangan teknologi yang makin maju, dakwah merupakan hal yang sangat penting untuk selalu mengiringi masyarakat seiring dengan kemajuan zaman ini, karena banyak sekali tantangan yang akan terus dilewati dalam melakukan dakwah atau bimbingan terhadap masyarakat.

Dengan kemajuan era teknologi dan informasi seseorang dapat melihat dilayar kaca, banyak lahir dai dan daiah berdakwah melalui media televisi dan bahkan adapula lewat radio, media cetak, dan jejaring sosia menjadi wadah dalam melakukan aktivitas dakwah. Namun dengan lahirnya penceramah/pendakwah seolah belum mampu melawan lahirnya penyimpangan-penyimpangan dan kriminalitas dalam masyarakat seperti, pemerkosaan, durhaka kepada orang tua, minuman keras, rampok, bahkan perselingkuhan dalam rumah tangga, dan untuk kalangan pemuda adalah pergaulan bebas, terjerat narkoba, mencuri, tawuran, dan lain-lain. Kesemuanya merupakan penyakit masyarakat yang disebut dengan Patologi social. Bahkan kejujuran juga sudah langkah di negeri ini, korupsi nyaris terjadi disemua lapisan masyarakat, dari pegawai rendahan hingga pejabat teras, dan dari prajurit sampai komandan. Itulah fenomena penyakit masyarakat sekarang ini yang merupakan beban bersama sebagai umat manusia yang cukup menjadi keprihatinan tersendiri dan khususnya penulis atas perilaku penyimpangan tersebut.

Aktifitas dakwah yang dilakukan pendakwah seoalah hanya sekedar memenuhi panggilan dari panitia pelaksana tanpa memikirkan apa kajian atau materi yang tepat untuk dibawah dalam kegiatan tersebut. Khususnya di Sinjai, banyak majelis-majelis talim yang terbentuk tapi sasaran materi dakwahnya belum tepat. Hal ini dikarenakan gerakan dakwah tersebut tidak dilakukan secara sistimatis tetapi hanya dengan materi lepas, sehingga terkadang materi yang di sampaikan berulang pada tempat yang sama.Meskipun masih ada sebagian pendakwah tetap menyajikan materi dan bahan dakwah secara berkala dan sistimatis. tetapi tidak semua pendakwah melakukannya. 
Melalui tulisan ini penulis mencoba melakukan tinjauan melalui psikologi diagnostik yang penulis lihat cukup layak menjadi rujukan dalam mewujudkan efektifitas dakwah. Alasannya psikologi diagnostik merupakan sentral dari cabangcabangi ilmu psikologi yang ada. Melalui psikologi diagnostik seseorang dapat melakukan analisis masalah secara kompleks terhadap masyarakat sehingga para pendakwah dengan mudah melakukan bimbingan terhadap masyarakat sesuai dengan apa yang menjadi landasan atau kebutuhan masyarakat yang berkaitan dengan masalah dakwah ataupun bimbingan itu sendiri.

\section{Efektivitas Dakwah melalui Bimbingan}

Berdakwah memang tidak mudah, karena berdakwah melalui proses bimbingan ibarat menanam pohon jati, yang harus senantiasa dijaga dan dipelihara sehingga akarnya tetap kuat menghujam kokoh ditanah dan tidak goyah diterpa angin kencang, oleh karena itu jalan bimbingan adalah proses menuju pembentukan pribadi yang paten, atau dengan kata lain memiliki imunitas baik secaramoralgagasan dan pemikiran, serta struktural

Dibawah ini adalah pengertian dakwah menurut istilah dari beberapa pakar,sebagai berikut :

H.M.Thoha Yahya Umar menyatakan :

Dakwah ialah mengajak manusia dengan cara bijaksana kepada jalan yang benar yang sesuai dengan perintah Tuhan kemaslahatan dan kebahagiaan didunia dan di ahirat. ${ }^{2}$

Syaikh Ali Mahfudz menyatakan :

Dakwah adalah mendorong(memotvasi) manusia untuk melakukan kebaikan dan mengikuti pentunjuk, memerintahkan mereka berbuat ma'ruf dan mencegahnya dari perbuatan mungkar agar mereka memperoleh kebaikan dunia dan akhirat. ${ }^{3}$

\footnotetext{
${ }^{2}$ Totok Jumantoro,Psikologi Dakwah: dengan Aspek-Aspek Kejiwaan yang Qurani,(Cet.1:Amzah,2001)h.18

${ }^{3}$ Totok Jumantoro, Psikologi Dakwah: dengan Aspek-Aspek Kejiwaan yang Qurani, h.17
} 
Aktivitas dakwah hakikatnya tidak tidak jauh beda dengan proses komunikasi karna pada dasarnya dakwah merupakan penyampaian informasi agama atau penyebaran ajaran Islam melalui proses komunikasi. Sehingga keberhasilan dakwah tidak lepas dari bagaimana cara pendakwah menjadi komunikator yang baik.

\section{Unsur yang Berkaitan dengan Keefektifan Dakwah}

a. Komunikasi

Defenisi komunikasi menurut Katz menyatakan :

Komunikasi merupakan proses penyampaian dan penerimaan lambanglambang yang mengandung arti, baik yang berwujud informasi-informasi, pemikiranpemikiran, pengetahuan ataupun yang lain dari penyampai atau komunikator kepada penerima atau komunikan dan dalam komunikasi yang penting adanya saling pengertian bersama dari lambing-lambang tersebut, dan karena itu komunikasi merupakan proses sosial. ${ }^{4}$

Dalam hal ini komunikasi dan sebagian dari ilmu komunikasi memberikan peran agar dengan proses dakwah dalam melakukan bimbingan yang melibatkan komunikasi tersebut, dapat terjadi penjabaran, penterjemahan, dan pelaksanaan Islam dalam segala aspek kehidupan manusia dalam bermasyarakat, termasuk politik, ekonomi, sosial, pendidikan, dan ilmu pengetahuan kesenian, kekeluargaan, kewarganegaraan dan sebagainya yang mencakup aktifitas manusia itu sendiri.

a. Penyajian Materi

Penyajian materi sesuatu hal yang sangat erat hubungannya dengan latar belakang sosial masyarakat dan kondisi psikologi masyarakat pada umumnya agar bahan yang disajikan lebih terarah dan dapat dikembangkangkan sesuai kebutuhan masyarakat tersebut.

\footnotetext{
${ }^{4}$ Bimo walgito ,Psikologi sosial (yograkarta:Andi offset,2003),h.75.
} 
b. Keteladanan

Berhasil tidaknya dakwah melekat pada diri seorang pendakwah karena yang berpengaruh bukan saja apa yang dikatakan tetapi apa yang dilakukan pendakwah tersebut. Dengan kata lain keteladanan seorang pendakwah sangat diperlukan demi suksesnya aktifitas dakwah. Misal: perbuatan yang di lakukan secara terbuka oleh dai, menyebabkan ajakan dakwahnya tidak di dengar, karena perilaku seorang dai merupakan satu bangunan dengan apa yang dikatakan.

d. Interaksi sosial

Merupakan hubungan timbal balik antara manusia yang satu dengan manusia yang lain dalam kehidupan bermasyarakat sebagai mahluk sosial walaupun cenderung bersifat individual. Maka dalam hal ini interaksi sosial dengan masyarakat untuk seorang pendakwah dalam melakukan bimbingan itu sangat di perlukan dengan menyampingkan sedikit kepentingan pribadi agar pendakwah mendapat simpati dari masyarakat.

\section{Tinjauan Tentang Psikologi Diagostik}

Istilah psikologi diagnostik berawal ketika Herman Rorschach menerbitkan hasil penelitiannya dengan metodenya yang diberi judul psikodiagnostik maka Herman Rorschach menyatakan :

Psikologi diagnostik adalah metode yang digunakan untuk menetapkan kelainan-kelainan psikis, dengan tujuan untuk mendapatkan pertolongan secara akurat dan tepat. ${ }^{5}$

Pada mulanya psikologi diagnostik untuk memecahkan persoalan-persoalan praktis,baik pada individu maupun kelompok,institusi atau bidang-bidang sosial, dan selanjutnya lebih berkembang bidang penerapannya pada obyek material dan obyek formal. Pada akhirnya psikodiagnostik menjadi bahan rujukan dari para psikolog sebagai materi analisis untuk pengkajian terhadap permasalahan-permasalahan yang timbul dalam segala aspek.

${ }^{5}$ Wijaya Agus, Defenisi Dan Pengantar Psikologi Diagnostik, diambil pada bulan November 2012, dariwww.scibd.com/dq/19339343/psikodiagnosic.com,oktober 2008 
Pengertian lain yang penulis salin dari sumber artikel lainnya, yang menjelaskan bahwa psikologidiagnostik adalah studi ilmiah tentang berbagai metode untuk membuat diagnostik psikologis, dalam tujuan supaya dapat memperlakukan manusia dengan lebih tepat.

Dasar untuk melakukan peninjauan dalam efektifitas dakwah dalam melakukan bimbingan terhadap masyarakat melalui teori tersebut karena psikologi diagnostik memiliki kedudukan sentral yang merupakan alat utama bagi psikolog melakukan tugas utamanya dalam membantu manusia yang menyangkut masalah kejiwaan, jadi dengan melakukan peninjauan dengan menggunakan metode dari psikologi diagnostik maka harapan untuk menggapai puncak dalam keberhasilan dakwah akan menjadi realita.

Psikologi diagnostik memiliki fungsi yaitu untuk mengetahui perkembangan psikologi individu dalam menghadapi persoalan dalam hidup dan lingkungannya, karena individu yang hidup dilingkungan sosial yang memiliki latar belakang status sosial yang berbeda, dalam segi pendidikan, perilaku dan lain-lainnya. Tujuan penulis sendiri sebagai kebutuhan untuk membuat diagnostik adalah karena manusia sangat berperan penting dalam seluruh aspek kehidupan.

Demikian pula untuk melakukan pelayanan bimbingan kepada masyarakat diperlukan loyalitas dan empati yang tinggi dan keprofesionalan terhadap masalah yang dihadapi masyarakat serta pelayanan dengan hati itu sangat perlu, karena bagi penulis hal itu mutlak diperlukan untuk seorang pembimbing atau pendakwah untuk melayani dengan hati,sebab secara tidak langsung ada hubungan psikologis atau emosional akan terbentuk sehingga dalam melakukan bimbingan ataupun pemberian bantuan terhadap masalah yang dihadapi masyarakat baik secara individual maupun kelompok pandakwah melakukannya dengan senang hati tanpa paksaan dan pamrih dan unsur lainnya, tetapi karena berlandaskan kasih sayang antar sesame. Karena sesungguhnya manusia merupakan mahluk sosial yang saling membutuhkan antara satu dan lainnya. 
Namun perlu diakui dengan adanya program pemerintah dapat membantu para dai/pembimbing yang bekerja di Kementrian Agama sebagai penyuluh dapat mengetahui dan mendiagnosa langsung penyakit/masalah yang timbul di masyarakat secara spesifik hingga dapat membantu mereka dalam menyelesaikan permasalahan yang mereka hadapi. Ini merupakan program kerja pemerintah yang cukup baik dan ini perlu diberikan apresiasi melalui program Suscatin tersebut.

Pengamatan penulis di Sinjai Utara penulis bertemu langsung dengan penyuluh agama KUA Sinjai utara yang bertempat tinggal kelurahan Bongki beliau bernama Pak. Burhanyang menyatakan bahwa :

Dakwah dikatakan efektif adalah dakwah yang dilakukan sesuai dengan kebutuhan masyarakat dan Metode dakwah QaulanSadida yang bisa diterima semua lapisan masyarakat serta keteladanan pendakwah sebagai subjek dakwah ${ }^{6}$

Masyarakat Sinjai yang khususnya berada di tengah kota Sinjai tepatnya kelurahan Bongki termasuk masyarakat religi meskipun masyarakatnya rata-rata pengusaha ataupun pedagang. Hal ini dikarenakan kondisi lingkungan yang sebagian masyarakatnya berdekatan dengan wilayah pesantren yaitu pesantren "Darul Falah" dan "Pesantern Istiqomah" dan berbagai organisasi masyarakat yang berbasis agama.

Dari hasil wawancarapun beliau berpendapat bahwa metode dakwah secara sistimatis tidak terlalu efektif untuk masyarakat yang berada di kelurahan Bongki yang termasuk masyarakat Kota dalam penggunaan media komputer dengan alat pryektor/LCD untuk memberikan materi. Komentar beliau bahwa penggunaan lewat media tersebut kurang efektif alasannya masyarakat tidak akan terlalu memperhatikan materi yang diberikannya.

Ini berbeda dengan pernyataan masyarakat yang berada di kecamatan Tellu limpoe dan kecamatan Sinjai Utara, justru mereka berpendapat dengan menggunakan media computer dengan alat bantu $\mathrm{LCD} /$ proyektor itu justru menjadi daya tarik untuk masyarakat dan sekaligus memperkenal kepada masyarakat tentang teknologi

\footnotetext{
${ }^{6}$ Burhan, Penyuluh Agama Kec.Sinjai Utara, Objek Dakwahnya Di Kelurahan Bongki Sekaligus Imam Mesjid Yang Berada Di Kelurahan Bongki.
} 
khususnya yang berada di daerah terpencil dan merupakan metode dan strategi agar dakwah bimbingan terasa segar dan menyenangkan karena ada sesuatu yang baru dan berbeda dari bimbingan biasanya. Tanggapan tersebut didukung oleh beberapa pendakwah diantaranya bu Deska,Ustdzah Rabiah, dan Ningsih serta bu Lina, Ka Rani bahwa penggunaan media computer cukup bagus dipergunakan dalam berdakwah. $^{7}$

Hal senada di ungkapkan Ibu Deska, bahwa :

Berdakwah dengan menggunakan Computer terhadap masyarakat harus diketahui dulu kelebihan dan kekurangannnya apabila disajikan kepada masyarakat, contoh: untuk masyarakat kota tidaklah masalah bila langsung ke pembahasan materi dengan menggunakan proyektor/LCD. tetapi untuk masyarakat Desa alangkah baiknya kita mememutark film atau Video yang membangkitkan nurani dan video motivasi-motivasi dan kemudian dilanjutkan dengan materi dakwah atau bimbingan dan ini salah satu dakwah bisa jadi menarik dan efektif karena memilki daya tarik tersendiri. ${ }^{8}$

Dakwah bisa efektif apabila para pendakwah baik yang terikat secara formal maupun non formal atau dalam naungan pemeritah maupun ormas harus melakukan dengan hati dan bersugnguh-sungguh, bukan hanya sekedar memberikan materi tanpa ada tindak lanjutnya. Pendakwah harus mempunyai alokasi waktu secara khusus tanpa menunggu panggilan atau hanya sekedar memenuhi panggilan untuk melakukan dakwah terhadap masyarakat.

\footnotetext{
${ }^{7}$ Rani, Pengurus Majelis Ta'lim Dusu Manalohe Desa Samaturue. Wawancara Pada Tanggal 23 Mei 2012 Di Mesji Imadul Jihad. Dan hasil wawancara dengan penyuluh agama yang ber ada di kec.sinjai utara.

${ }^{8}$ Salah Satu Pendakwah /Dai' ah Yang Memberikan Bimbingan Dengan Menggunakan Media Computer (LCD/Proyektor), Wawancara Pada Tanggal 17 Mei 2012
} 


\section{Tinjauan Umum Aktivitas Dakwah Di Kabupaten Sinjai Dalam Menunjang Efektifitas Dakwah}

Pada umumnya aktivitas dakwah masyarakat Sinjai sudah berjalan cukup baik ini dapat dilihat dari kegiatan-kegiatan agama yang dilakukan hampir di setiap Kecamatan dan Desa, seperti terbentuknya majelis-majelis ta'lim untuk kaum ibu, dan ini sudah terbentuk dari tingkat Kabupaten dan Kecamatan bahkan sampai ke tingkat Desa meskipun belum maksimal. Namun sudah dapat terlihat adanya upayaupaya dari masyarakat sendiri dan sebagian para pendakwah yang mau melakukan/membentuk kegiatan/pengajian tersebut. Dari sekian banyak Mesjid yang tersebar di setiap Kecamatan hanya ada beberapa mesjid disetiap Desanya yang memiliki Majelis Talim. Sehingga metode ceramah yang umum dilakukan oleh para pendakwah/penyuluh di Kemenag belum mampu membuahkan hasil karena diantara penyuluh-penyuluh yang terdaftar sebagai tenaga penyuluh Non PNS kurang menguasai metode dakwah.

Untuk Ormas-ormas Islam merupakan gerakan dakwah yang berada di Sinjai. Jika dilihat berdasarkan pengamatan penulis, ormas Islam tersebut telah melakukan upaya-upaya untuk melakukan kegiatan dakwah melalui bimbingan. Diantaranya adalah $:^{9}$

\section{Muhammadiyah}

Muhammadiyah yang berada Sinjai, untuk gerakan dakwahnya sudah berjalan namun pada umumnya belum dilakukan secara intens. Umumnya hanya dilakukan pada waktu-waktu tertentu, tetapi untuk ortom Muhammadiyah lainnya seperti Ikatan Remaja Muhammadiyah (IRM), Ikatan Mahasiswa Muhammadiyah (IMM), walaupun belum terlalu rutin melakukan kegiatan yang melibatkan masyarakat diluar Kader Muhammdiyah, tapi gerakan dakwahnya melalui pengkaderan terhadap pelajar pemuda dan kalangan mahasiswa dapat diperhitungkan sebagai penunjang dalam efektifitas dakwah yang berada di Kabupaten Sinjai. hal ini

\footnotetext{
${ }^{9}$ Hasil Observasi dan Wawancara, dari beberapa anggota kader dari organisasi/lembaga tersebut, pada tanggal 18 dan 25 mei 2012.
} 
dapat dilihat lahirnya kader-kader yang dibina selama kurang lebih satu minggu, diantaranya mencetak kader terbaik yang selalu giat berdakwah dalam wilayah kampus, dengan melakukan kajian-kajian islami yang sering diadakan dalam kampus STAIM Sinjai.

\section{Darul Istiqomah}

Gerakan dakwahnya melalui metode bimbingan walaupun lebih cenderung dalam wilayah pesantren tapi dengan memiliki sistim yang baik dan jaringan yang bagus terhadap masyarakat dalam gerakan dakwahnya, dan sosialisasi dan interaksi yang harmonis terhadap masyarakat, serta keteladanan yang baik pula oleh para pendakwahnya, gerakan dakwahnya bisa diterima oleh segala lapisan masyarakat yang cenderung mempengaruhi lingkungan yang berada disekitarnya.

Pesantren tersebut sering melakukan kegiatan rutin setiap bulannya tepat setiap tanggal 14, dan sudah kurang-lebih tiga bulan berjalan, pihak pesantren melakukan kegiatan berupa mutabaah yang setiap jamaah bersedia menyetor segala aktivitas kegiatan keagamaan kepada Pembina pondok setiap pertemuan seperti; (setor hafalan Alquran dan Hadist, laporan silaturahmi disanak saudara, shalat dhuha, tahajjud, dan ibadah-ibadah sunnah lainnya).

Setiap tanggal 15 yang berada di Pucee kec. Sinjai Selatan, serta setiap minggunya melakukan pengajian dengan metode bimbingan. Dalam pengajian ini banyak masyarakat hadir dari berbagai desa yang tersebar diwilayah kabupaten sinjai, karena pengajian rutin tersebut terbuka untuk masyarakat umum bukan hanya kalangan pesantren. Santri-santriwati pesantren beserta masyarakat yang berada dilingkungan sekitar tersebut memiliki karakter yang kuat, sehingga mereka mudah dikenali sebagai jamaah pengajian pesantren DarulIstiqomah. ${ }^{10}$

\section{Lembaga Wahdah Islamiyah}

Lembaga dakwah inipun memiliki jaringan yang banyak hampir disetiap Kabupaten/Kota, dan untuk Sinjai sendiri kader-kadernya pula telah tersebar disetiap

\footnotetext{
${ }^{10} \mathrm{Ika}$, Pembina pondok pesantren Darul istiqomah/ Al-Markaz, Wawancara
} 
Kecamatan dan Desa bahkan di sekolah-sekolah dengan melakukan bimbingan setiap pekannya. Jaringannya cukup bagus, karena lembaga tersebut memiliki kader-kader yang professional yang telah di godok dengan melewati jenjang pendidikan yang sesuai dengan kurikulum yang berlaku dilembaga tersebut atau yang biasa disebut tarbiyah. Lembaga ini melakukan bimbingan empat-lima kali dalam sebulan, tersistim dan terorganisir. Lembaga wahdah Islamiyah dalam berdakwah telah menyediakan waktu khusus dalam berdakwah dimasyarakat dan di kalangan internal, hal ini agar lebih termenej waktu produktif dalam berdakwah, seperti; (setiap minggunya disediakan waktu khusus bersifat materi lepas yang sesuai dengan perkembangan atau issu terkini yang berkembang di masyarakat materi tersebut bisa untuk kader Wahdah dan masyarakat umum. Untuk majelis Ta'lim berdasarkan permintaan mad'u atau masyarakat dan materi yang disajikan bersifat lepas namun tetap memperhatikan kondisi masyarakat setempat dan materinya sesuai yang menjadi kebutuhan masyarakat tersebut, dan sistim tarbiyah rutin dilaksanakan khusus untuk kader yang berdasarkan jenjang tarbiyah. ${ }^{11}$

\section{Peran Pendakwah Tinjauan melalaui psikologi Diagnostik}

Berdasarkan pengamatan penulis dakwah yang berada dikabupaten Sinjai cukup baik karena sebagian masyarakat memiliki kesadaran ingin mempelajari ilmu pengetahuan agama, baik lewat pembentukan Majelis-majelis Talim dan seminarseminar agama, dan tak lupa media elektronik yaitu; berupa Radio dan Televisi berperan dalam memberikan informasi-informasi yang dapat menambah wawasan dan cakrawala berpikir masyarakat. Dakwah-dakwah yang berada lingkungan pesantren dan wadah-wadah organisasi secara tidak langsung berperan dalam mempengaruhi lingkungan yang berada disekitarnya.

Untuk dakwah yang berada dilingkungan pesantren cukup efektif berbeda dengan pandangan umum tentang efektifitas dakwah secara keseluruhan yang berada

\footnotetext{
${ }^{11}$ Hasil Observasi Dan Wawancara Hari Jumat Tanggal 18 Mei 2012
} 
di Wilayah Kab.Sinjai, karena dakwah yang dilakukan di Pesantren menggunakan metode bimbingan yang dilakukan secara berkala kepada anak-anak bimbingnya.

Namun jika dikaji secara umum aktifitas dakwah yang dilakukan tersebut belum terlalu berbuah manis dalam efektifitas dakwah secara menyeluruh, karena belum adanya kerangka pikir yang dibangun secara bersama dengan niat yang baik dan kesadaran yang tinggi bagi pendakwah yang berada disektor pemerintahan maupun pesantren-pesantren atau organisasi keagamaan dalam menyatukan pemikiran untuk bersama-sama menggunakan konsep yang sama(satu) dan tersistim serta dikerjakan dengan niat bersungguh-sungguh dan keihklasan melakukan dakwah dengan menggunakan metode bimbingan, yang bukan hanya sekedar panggilan tapi para pendakwah sebagai pembimbing masyarakat harusnya senantiasa melakukan intreaksi sosial dan followup terhadap masyarakat.

Bahkan masih ada masyarakat yang belum terjamah atau tersentuh oleh dakwah secara intensif. Ini diperlukan kerjasama yang solid antara pemerintah dan lembaga-lembaga, ormas-ormas yang berbasis agama. Ini menjadi wacana yang serius untuk pendakwah-pendakwah yang berada dipemerintahan maupun lembagalembaga keislaman.

Hasil observasi dan wawancara yang dilakukanpenulis bahwasannya peran pendakwah yang berada di Kab. Sinjai pada umumnya belum maksimal dan ini dikatakan langsung oleh beberapa anggota masyarakat dari berbagai lapisan, ibu rumah tangga, tokoh masyarakat, mahasiswa dan bahkan kepada tokoh agama yang penulis meminta pandangannya secara objektif terhadap peran pendakwah walaupun beliau sendiri sebagai seorang mubaligh dan jawabannya hampir sama dengan tanggapan masyarakat pada umumnya.

Diantara mereka sebagian berpendapat bahwasannnya peran pendakwah belum terlalu maksimal atau masih kurang dan belum merata contoh: masyarakat yang berada disinjai Tengah mereka dalam melakukan kegiatan keagamaan atau membutuhkan seorang penceramah harus lebih dulu memanggil ustad yang berada diluar Kecamatan mereka.Ini disampaikan oleh masyarakat yang bermukim di Sinjai 
Tengah bernama Faisal, yang saat itu salah satu dari anggota keluarganya meninggal dunia,tetapi tidak ada seorang mubalig diwilayahnya yang bisa di panggil untuk membawakan materi ceramah takziyah akhirnya harus memanggil penceramah dari luar. Bahkan di desanya khususnya Desa Baru Kec.Sinjai Tengah, tidak ada majelis ilmu dimana masyarakat dapat menerima informasi-informasi dan pengetahuan agama agar mereka mengetahui pengetahuan agama. Mereka mengetahuihanya melalui pelajaran di sekolah, bangku kuliah untuk pelajar, dan ibu rumah tangga dan bapak-bapak dari media Televisi siaran (mama dan Aa dan Ustad Maulana, serta khutbah jumat untuk kaum bapak ). ${ }^{12}$

Untuk penulis ini cukup memprihatinkan padahal jika dilihat kuantitas pendakwah yang berada di Sinjai cukup untuk menunjang keefektifan dakwah yang dilakukan secara merata bahkan bisa sampai ke daerah terpencil.Para pendakwah yang sudah lama berkiprah baiknya melakukan pelatihan-pelatihan dai professional yang bekerja sama dengan pemerintah setempat yang diambil masing-masing perwakilan disetiap kecamatan atau desa untuk pelaksanaan kegiatan pelatihan dai atau namanya lebih bergengsi disebut dengan public spekear. ${ }^{13}$

Tanggapan dari masyarakat lainnya pada umumnya pendakwah lebih cenderung mendikte, bukan memberikan pemahamam yang kongkrit hal ini dikarenakan pendakwah hanya sekedar memenuhi panggilan dan tidak melakukan persiapan materi apa yang cocok untuk kebutuhan mad'u-nya dan kurangnya strategi dakwah dalam melakukan bimbingan terhadap masyarakat.

menurut pendapat Ningsih :

Kurangnya efektifitas dakwah disebabkan banyak pendakwah tidakdiberikan bimbingan atau pembinaan pula secara berkala yang sesuai dengan mampuan

\footnotetext{
${ }^{12}$ Faisal, Wawancara Pada Tanggal 17 Mei 2012, Mahasiswa STAIM Sinjai Yang Berasal Dari Kecamatan Sinjai Tengah.

${ }^{13}$ Public Speaker bentuk pelatihan dalam berbicara didepan umum atau orang banyak untuk melatih keberanian dengan mengasah ketrampilan baik berbicara maupun penyajian materi yang dapat menjadi daya tarik pendengar atau mad'u.
} 
pendakwah itu sendiri sehingga terkadang kualitaspendakwahpun masih $\operatorname{minim}^{14}$

Hal senada dikatakan oleh ibu rumah tangga sekaligus sebagai aktivis dakwah Ustadzah Rabiah yang sudah 27 tahun berkiprah didunia dakwah mengatakan:

Bahwa dikabupaten Sinjai memiliki bayak pendakwah tetapi kurang berperan kecuali para pendakwah-pendakwah yang berada dalam wadah organisasi dan pesantren, tetapi itu belum merata dalam menunjang efektifitas dakwah ${ }^{15}$

Tanggapan menurut Ibu Lina dan Kak Rani yang berada di Desa Samaturue Kecamatan Tellu limpoe, bahwa peran pendakwah yang berada di Desa Samaturue cukup efektif karena parapendakwah memberikan materi yang sesuai dengan kebutuhan masyarakat dan memiliki hubungan yang baik dan sebagai uswatunkhasanah bagi masyarakat dan mempengaruhi kondisi psikolog terhadap masyarakat serta berkualitas dalam memberikan perubahan terhadap masyarakat. ${ }^{16}$

Menurut salah satu masyarakat Sinjai Tengah yang bernama saudariTina, mengatakan bahwa peran pendakwah tidak terlalu nampak khususnya yang berada diDesanya kawasan Manimpahoi, namun dakwah tetap dapat berjalan atas insiatif dari masyarakat tersebut dengan mengundang ustadz-ustadz untuk mengisi majelis yang dibentuk oleh salah satu anggota masyarakat yang menurut saudari Tina itu termasuk Ta'lim keluarga yang di barengi dengan arisan dan diadakan di Mesjid, agar masyarakat umum dapat turut hadir dalam ta'lim tersebut yang diadakan sebulan sekali, namun menurut saudari Tina itu belum efektif dalam menunjang keberhasilan dakwah yang berada di Desanya. ${ }^{17}$

\footnotetext{
${ }^{14}$ Ningsih, Pengurus Lembaga Muslimah Sinjai, dan sebagai penanggung jawab lembaga Rohis dan kemahasisiwaan

${ }^{15}$ Rabiah, Ketua Persatuan Wanita Muslimah ( SALIMAH Sinjai, dan pemenang ummi awards tingkat propinsi Sulawesi Selatan).

${ }^{16}$ Lina,dkk. Pengurus majelis Talim Imaddul Jihad Desa Samaturue kec.Tellu Limpoe dan guru mengaji

${ }^{17}$ Tina, Wawancara pada bulan Mei 2012, pada saat mau perjalanan pulang Sinjai menuju Desa Manimpahoi Kec.Sinjai Tengah, di Halte dekat jembatan Mangottong.
} 
Berdakwah bukan pekerjaan biasa dan mudah, tetapi dakwah merupakan pekerjaan yang sangat mulia.Mulia, menuntut perhatian khusus dengan beberapa cara penyampaian yang kreatif. Jika tidak, dakwah tersebut akan kontra produktif. Seorang Da'i, harus mampu mengenal mad'u, menguasai materi dakwah yang akan disampaikan, serta harus menyesuaikan metode yang digunakan dengan mad'u atau sasaran dakwah. Harapan penuluis dalam penelitian ini bisa menjadi salah satu sajian alternatif untuk menganalisa keadaan mad'u/masyarakat yang dihadapi, serta beberapa cara mengatasi kegagalan dakwah dan untuk meningkatkan kualitas dakwah seorang da'i. Kendati pun kini aktifitas dakwah di kabupaten Sinjai yang penulis analisa mengalami penurunan kualitas dakwah kecuali dikawasan pesantren dan basis lembaga keagamaan.

\section{a) Bimbingan Individual}

Bimbingan individual adalah bentuk dakwah yang dilakukan melalui dari diri sendiri, keluarga, kemudian masyarakat yang dilakukan perorangan, atas panggilan hati atau rasa kesadaran yang tinggi dalam berdakwah, yang harus didukung dengan pengetahuan atau pendidikan baik formal maupun informal. Bimbingan individual tersebut diatas bisa pula di maknai atau diartikan sebagai bimbingan atau dakwah terhadap seseorang melalui pendekatan personal yang melibatkan ikatan emosional, yang dilakukan dengan menggunakan teknik dalam kegiatan atau praktek psikolog, hal ini akan dapat memudahkan pendakwah dalam berdakwah dan mengetahui permasalahan yang dihadapi mad'u.

b) Bimbingan Kelompok

Dakwah yang dilakukan lebih dari satu orang yang dilakukan atas asas kebersamaan dalam bentuk wadah atau organisasi dengan menggunakan landasan yang sama dan pola pikir dan sistim yang sama pula agar dakwah bimbingan dapat terarah dan memenuhi harapan yang sesuai dengan target yang ingin dicapai secara bersama-sama demi untuk kemaslahatan umat. Dengan aktifitas`kelompok tersebut bertujuan agar dakwah tidak terasa jenuh atau membosankan, tetapi justru menimbulkan rasa kerinduan antar sesama anggota apabila lama tidak ketemu dalam 
majelis atau kegiatan keagamaan. Hal ini dikarenakan telah terjalin hubungan emosional yang cukup kuat antar sesama anggota.

c) Gabungan Baik Individual, Kelompok dan Lembaga atau Instansi Terkait

Hai ini merupakan dakwah bimbingan dalam bentuk gabungan yang saling terkait dalam hubungan kerja sama yang baik, dalam menyelenggarakan kegiatankegiatan keagamaan dalam meningkatkan mutu pendidikan dari segala sektor, serta pemberdayaan dan meningkatkan kualitas dan kreatifitas sumberdaya manusia yaitu masyarakat, baik anak-anak, remaja, dewasa. Hal ini merupakan kolaborasi yang baik. jika ini benar-benar terwujud secara maksimal khususnya masyarakat yang berada dikabupaten sinjai. Contoh : pelaku dakwah baik perorangan maupun kelompok, hendaknya membina hubungan yang baik dengan pemerintah atau bekerja sama, dengan melibatkan pemerintah disetiap kegiatan-kegiatan dakwah yang diselenggarakan.

\section{Upaya Meningkatkan Kualitas Dakwah Mencapai Keefektifan Dalam Melakukan Bimbingan Terhadap Masyarakat}

Upaya untuk meningkatkan kualitas dakwah adalah mendiagnosa permasalahan yang dihadapi masyarakat kemudian dilanjutkan dengan pendekatan khusus. Upaya ini dilakukan untuk menarik simpati masyarakat agar hatinya bisa ditembus dan bisa menerima dakwah yang disampaikan, karena pendekatan yang khusus dapat menjalin hubungan yang baik dengan masyarakat.

Bimbingan yang dilakukan oleh pendakwah harus dilakukan dengan intens sehingga masyarakat lebih kenal dekat dengan pendakwah, dari sanalah materi dakwah akan mudah diterima dan menjadi sebuah kebutuhan bukan menjadi sebuah pelengkap identitas keislaman sebuah daerah. Adapun hal yang harus dilakukan adalah:

1. Adanya wadah, badan atau kelompok orang yang terorganisir.

2. Adanya tenaga yang potensial, terdiri dari beberapa orang dengan pembagian tugas yang sesuai dengan kemampuan masing-masing seperti: tenaga pengelola/koor, dan pelaksana lapangan, tenaga yang berpengetahuan 
akademis dan berkompoten, dan tenaga penambahan untuk mubaligh, dan tenaga yang penghimpun dana.

3. Mengembangkan dana dan sarana-sarana yang diperlukan dalam masyarakat.

4. Adanya rencana program walaupun sederhana agar menunjang aktifitas`dakwah.

5. Adanya pendekatan atau interaksi terlebih dahulu dengan masyarakat, dan membina hubungan yang baik dengan instansi-instansi dan lembaga-lembaga pemerintahan agar perjalanan dakwah mendapat naungan dari pemerintah setempat baik mori maupun materi. Langkah ini sangat membantu. ${ }^{18}$

Untuk meningkatkan efektifitas dakwah yang diperhatikan adalah ciri masyarakat yang menjadi sasaran dakwah oleh pendakawah, karena dalam memberikan dakwah melalui bimbingan tehadap masyarakat kondisi pendidikan, dan faktor psikolog masyarakat perlu di perhatikan. Dan dalam tulisan ini penuli mencoba membedakan bimbingan dakwah untuk masyarakat Kota dan masyarakat yang berada di Desa.

Karena untuk masyarakat Kota dakwah melalui bimbingan yang perlu diperhatikan adalah masalah waktu luang bagi masyarakat kota karena berdasarkan survey yang dilakukan, bahwa masyarakat tersebut untuk pagi sampai sore harinya, mereka cenderung sibuk, karena mereka yang rata-ratanya pedagang, pegawai kantoran baik swasta maupun PNS. Sehingga waktu seperti yang tersebut diatas mereka kurang siap jika dilakukan dakwah pada waktu-waktu tersebut.

Di bawah ini ada beberapa hal penting dalam melakukan dakwah melalui bimbingan untuk masyarakat Kota dan Desa.

\section{a. Masyarakat kota}

Berdasarkan hasil analisis penelitian untuk masyarakat kota diantaranya:

1) Menghidupkan pengajian malam yang dilakukan secara intens diantara shalat magrib dan isya (seminggu dua kali ) .

\footnotetext{
${ }^{18}$ Berdasarkan Hasil Observasi dan Wawancara selama Penelitian
} 
2) Durasi waktu yang tidak terlalu lama (tidak lebih dari satu jam) dalam melakukan bimbingan, tetapi dilakukan dengan waktu yang intens ( seminggu dua kali )

3) Menggunakan media computer dan LCD/proyektor, agar bimbingan lebih hidup dan terkesan mengikuti perkembangan teknologi.

4) Jika perlu sesekali mengadakan games/permainan bersifat membangun untuk lebih menyegarkan suasana.

5) Berikan kesempatan kepada peserta bimbing untuk bertanya menceritakan permasalahan yang dihadapinya, dan jika terlihat serius . maka pembimbing menanganinya dengan cara melakukan pertemuan khusus face to face atau berdua, dan jika cukup pelik permasalahan yang dihadapinya maka pembimbing harus alih tangan dalam artian menyerahkan kepada yang lebih berkompoten dalam menangani permasalahan yang dihadapi masyarakat yang bersifat privacy (pribadi).

6) Langkah awal Materi dakwah temanya lebih cenderung yang disukai mengarah kepada masalah seputar keluarga dan masalah yang berkaitan dengan hati/jiwa. Alasannnya karena materi tersebut sebagai penarik dan merupakan tema yang bagus untuk langkah awal dalam melakukan bimbingan karena permasalahan yang dihadapi masyarakat kota cenderung masalah keluarga (suami/istri, anak, mertua/menantu, ipar, dsbnya), dan tekanan jiwa karena rata-rata masyarakat kota adalah masyarakat yang sibuk dengan segala aktifitas, sehingga perasaan galau, gelisah seringkali mereka temui sehingga membuat mereka mengalami kegersangan jiwa (hati).

7) Setelah ukhuwah terjalin maka lakukanlah dengan materi selanjutnya untuk memeperdalam ilmu agama, dengan memberika tugas, untuk melakukan ibadah-ibadah sunnah, seperti, tahajjud, dhuha, sedeqah menghafal al-quran dan hadist.dll. ${ }^{19}$

\footnotetext{
${ }^{19}$ Ditulis Berdasarkan Hasil Observasi Dan Wawancara .
} 


\section{b. Masyarakat Desa}

Berdasarkan hasil analisis lewat pengamatan dan wawancara dari masyarakat :

1) Paling utama dalam masyarakat desa adalah keteladanan dan interaksi sosial yang baik terhadap masyarakat

2) Materi yang disajikan tentang ahlak terutama ahlaq yang baik dan tutur kata yang santun dan bijaksana

3) Dalam melakukan bimbingan waktu yang efektif sebulan dua sampai tiga kali dalam sebulan

4) Perlu adanya daya penarik seperti nonton bareng " film nuansa Islami " yang bisa membangkitkan motovasi untuk mengenal dan dekat dengan Allah melalui media computer LCD/Proyektor

5) Sesekali mengundang pendakwah yang berada diluar Desa

6) Mengadakan Wisata Dakwah atau Taddabur alam di tempat Objek Wisata. ${ }^{20}$

\section{Dampak Pelaksanaan Bimbingan terhadap Masyarakat}

Berdasarkan pengamatan dan wawancara yang dilakukan oleh penulis, untuk Sinjai penerapan melakukan bimbingan terhadap masyarakat tidak semua pendakwah melakukan metode bimbingan terhadap masyarakat. Terutama pemerintahan dari Kementrian Agama telah memprogramkan dengan mengarahkan penyuluh-penyuluh agama baik PNS maupun non PNS untuk melakukukan bimbingan penyuluhan terhadap masyarakat, tetapi dari temuan penelitian itu belum maksimal dijalankan. Namun ada diantara para da'I dan da'iah ada yang telah melakukan bimbingan ke masyarakat secara intens dan berkala, serta tersistim. hasilnya cukup signifikan secara kualitas, salah satu dampak berhasilnya metode bimbingan tersebut terdapat di dusun Korong satu Kec. Tellu Limpoe, yang pembimbingnya adalah Ustad Dahlan yang sejak tahun 1990-an memulai dakwahnya diwilayah tersebut. Menurut penuturan beliau daerah yang ditempatinya sebagian masyarakatnya tidak memahami ilmu pengetahuan tentang agama, dan masyarakatnya tersebut senantiasa minum-minuman

\footnotetext{
${ }^{20}$ Analisis Dari Hasil Observasi Dan Wawancara
} 
keras walaupun pada bulan suci Ramadhan, namun berkat kegigihan beliau dalam membimbing masyarakat. Sekarang hasilnya dapat terlihat masyarakatnya sudah banyak memahami agama, dan kaum perempuannya sudah memakai jilbab yang syar'i, dan dibangunnya sebuah mesjid murni swadaya dari masyarakat setempat. ${ }^{21}$

Contoh yang berikutnya adalah untuk kalangan remaja yang dibimbing oleh Ustad Hamid setiap pekan, dampak dari bimbingan tersebut, contoh: pada saat pengumuman hasil ujian Nasional, untuk anak-anak didiknya mampu memperlihatkan perilaku yang baik, tidak melakukan konvoi di jalanan, serta aksi coret-menyoret, dan selalu melakukan hal-hal positif.Peserta bimbingan khusus kaum ibu dan perempuan yang dibimbing oleh IbuDeska dan ustadzah Rabiah, Ningsih, dampak dari hasil bimbingan mereka adalah antusis oleh peserta walaupun di usia yang tidak mudah lagi tidak malu untuk dibimbing mengaji dari awal (huruf Hijaiyah) dan mau belajar Shalat, sehingga mau menerapkan ilmu yang didapatnya, contoh: yang dulunya tidak pakai jilbab sekarang berjilbab, yang dulunya tidak shalat sekarang mau shalat bahkan shalat berjamaah di mesjid.

Jika apa yang dilakukan oleh para pendakwah yang tersebut diatas dilakukan oleh semua pendakwah dan penyuluh-penyuluh agama lainnya terhadap masyarakat dan bersatu dan memiliki komitmen yang sama maka hasilnya atau dampaknya akan semakin terlihat.

Jika dilihat berdasarkan analisis lapangan bahwa efektifitas dakwah melalui peran pendakwah jika dikaji dalam tinjauan psikologi diagnostic, pada dasarnya hampir sesuai dengan yang diharapkan, namun itu belum maksimal berdasarkan kerangka Tinjauan Psikologi Diagnostik

\footnotetext{
${ }^{21}$ Data, Wawancara pada Pra Observasi pada saat melakukan Kuliah Kerja Lapangan (KKL) di Kec.Tellue Limpoe
} 


\section{PENUTUP}

\section{Kesimpulan}

Penelitian ini, penulis menyimpulkan bahwa efektifitas dakwah di kabupaten sinjai belum merata, namun upaya-upaya yang dilakukan pemerintahan maupun lembaga yang berbasis islam sudah cukup baik. Tetapi dalam melakukan bimbingan terhadap masyarakat para pendakwah hanya sebatas memenuhi panggilan dari penyelenggara kegiatan keagamaan tanpa adanya upaya atau insiatif melakukan bimbingan secara itens dalam berberdakwah dan hanya terfokus pada pembentukan majelis talim yang hanya berlangsung sebulan sekali. Jika ini yang terjadi secara terus menerus maka dakwah yang berada di Kab. Sinjai akan bersifat statis atau jalan ditempat. Berdasarkan tinjauan melalui psikologi Diagnostik bahwasannya aktifitas dakwah belum efektif jika ditinjau secara spesifik tapi pada umum sudak cukup baik walaupun belum merata. Jadi melakukan dakwah bimbingan terhadap masyarakat maka diperlukan adanya analisis masyarakat yang akan menjadi sasaran dakwah dengan menggunakan metode bimbingan Psikologi Diagnostik, agar setiap apa yang menjadi keinginan atau kebutuhan masyarakat dapat terdeteksi secara dini. Masalah yang lain adalah masih kurangnya pendakwah-pendakwah perempuan.I

\section{Saran}

Sebaiknya pemerintah daerah dan kementrian agama RI melakukan penyeleksian yang ketat dan professional bagi para calon penyuluh/pendakwah sebagai pembimbing masyarakat, agar dakwah dapat berjalan lancar. Terutama pada saat pengambilan data karena bayak data yang masuk sebagai penyuluh sebagian yang terdata atas nama keluarganya sendiri yang tidak berkompoten sebagai penyuluh Agama.

Perluanya pelatihan dai-dai professional yang memiliki pengalaman yang baik dalam daerah maupun luar daerah.Untuk para aktifis dakwah baik indivdual maupun kelompok baiknya menjalin komunikasi yang baik dengan pemerintah daerah setempat dan bersama-sama bekerja melakukan dakwah dalam melakukan bimbingan terhadap masyarakat 
Untuk tokoh-tokoh masyarakat dan agama sebaiknya jangan hanya menunggu panggilan dan hanya memenuhi panggilan dalam berdakwah, tetapi harus menjadi Visioner dalam melakukan bimbingan terhadap masyarakat.Diperlukan adanya pengajian khusus untu kaum Bapak dan untuk Remaja, karena kebayakan yang meramaikan kegiatan dakwah hanya pengajianIbu-ibu atau majelis Talim.Dalam melakukan bimbingan sifat Sabar dan mau belajar serta Istiqomah itu merupakan hal yang paling penting dalam berdakwah untuk melakukan bimbingan, walaupun awalnya sulit tapi kemudian akan menjadi mudah. 


\section{DAFTAR PUSTAKA}

Arifuddin, NeuroPsikoLinguistik, CetI;Jakarta;PT.RajaGravindo Perkasa. 2010

Amir An-Najar, Ilmu Jiwa Dalam Tasawuf; Dalam studi komperatif dalam Ilmu Jiwa Kontemporer, Cet I:Jakarta Selatan, Pustaka Azzam.2000

AgustianGinanjarAry,ESQ:Rahasia Sukses Membangun Kecerdasan Emosi, Dan

Spiritual Cet.ke- 40:Jakarta,ARYa.2003

Andisupratnya,TinjauanPsikologis:KomunikasiAntarPribadi,Yogjakarta:

Kansius. 1995

Ahmad mubarok,PsikologiDakwah[t.d]

AliSariati,AnalisisSosiologiGerakanKeagamaanMasyarakatDari

AplikasiDakwah,artikel di ambildarillham Hamid,Tanggal 13 maret 2010

Aziz Ali, IlmuDakwah:EdisiRevisi, Cet. II;Bandung, KencanaPrenadaMediagruop. 2009

BurhanBungin, Analisis Data Penelitian Kualitatif: Pemehaman Filosofis Dan

MetodelogisKearahPenguasaan Model Aplikasi, PT raja gravindoperkasa, Jakarta. 2003

Deddymulyana,MetodelogiPenelitianKualitatif:ParadigmaBaruIlmuKomunikasi Dan IlmuSosialLainnya. Bandung : PT. RemajaRosdakarya. 2004

Emzir,MetodelogiPenelitianKualitatif;Analisis Data, CetakanKe. 1, Jakarta, Rajawali Press. 2010

Hasan,PenelitianDakwahArtikelDiambilPadaBulanJuni2012

Http://Www.Cyberdakwah.Net.Http://Dakwatuna.Com. Mei 2012

IsepZainalArifin,BimbinganPenyuluhanIslam:PengembanganDakwahMelaluiPsikote rapi Islam,Cet.I;Jakarta.PT.RayaGavindopersada, 2009

IbrahimElfiky,DahsyatnyaBerperasaanPositif;RahasiaMengelolaKekuatanPerasaan UntukMeningkatkanKetenangan Dan Kesuksesan, cet.1 ; Jakarta; Zaman. 2010 